УДК 619:616.98:636.8

(C) 2013

Борисевич Б. В., доктор ветеринарних наук, професор,

Лісова В. В., кандидат ветеринарних наук, Бондаренко О. В., аспірант*

Національний університет біоресурсів і природокористування України

\title{
МІКРОСКОПІЧНІ ЗМІНИ В ПЕЧІНЦІ КОТІВ ЗА КАЛІЦИВІРУСНОЇ ІНФЕКЦЇ̈
}

\section{Рецензент - доктор ветеринарних наук, професор В. Т. Хомич}

\begin{tabular}{|c|} 
Представлено результати гістологічних дослі- \\
джень печінки котів, які загинули від калічивірус- \\
ної інфекиї. Встановлено виразні запальні зміни, \\
що характеризувалися розширенням і переповнен- \\
ням кров'ю кровоносних судин, запальним набря- \\
ком паренхіми органа та ї̈ інфільтрацією кліти- \\
нами запалення. Такі зміни супроводжувалися \\
дистрофією й некрозом частини гепатоцитів. Під \\
капсулою печінки реєструвались осередки некрозу \\
гепаточитів, які не мали чітких меж. Некроз \\
печінкових клітин характеризувався каріолізисом. \\
\hline
\end{tabular}

Ключові слова: коти, калічивірусна інфекиія, патолого-анатомічна діагностика, мікроскопічні зміни, печінка.

Постановка проблеми. Каліцивірусна інфекція котів (каліцивіроз) - висококонтагіозна хвороба тварин родини Felidae, що клінічно проявляється кон'юнктивітом, виразковим стоматитом, ринітом, трахеобронхітом, пневмонією й супроводжується значною летальністю [4]. Хвороба вперше описана в 1957 р. у Новій Зеландії, проте до цього часу далеко не всі її аспекти достатньо вивчені. Переважна більшість робіт була присвячена розробці методів діагностики, лікування та профілактики каліцивірозу котів, у той час як іншим аспектам даної патології, в тому числі й патолого-анатомічним змінам, не надавалося достатньої уваги [5].

Аналіз останніх досліджень i публікацій, у яких започатковано розв'язання проблеми. У доступній літературі зазначено, що патологоанатомічні зміни варіюють залежно від штаму вірусу. Найчастіше реєструють виразки на дорсальній поверхні язика. Виразки можуть також локалізуватися на твердому піднебінні, губах і зовнішній поверхні ніздрів. Зміни в епітелії верхніх дихальних шляхів і кон'юнктиви менш помітні. Реплікація вірусу в суглобах відбувається в синовіальних макрофагах із макроскопічними й гістопатологічними проявами гострого перебігу. Ушкодження легень починається з вогнищевого альвеоліту, що призводить до вогнищевої ексудативної пневмонії й закінчується проліферативною інтерстиційною пневмонією [5-7]. В інших органах і тканинах патолого-анатомічні, особливо мікроскопічні, зміни майже не вивчалися.

Мета досліджень. Метою роботи було встановити мікроскопічні зміни в печінці котів, які загинули від каліцивірусної інфекції.

Матеріали і методи досліджень. Робота виконувалася на базі кафедри патологічної анатомії Національного університету біоресурсів i природокористування України. Діагноз на каліцивірусну інфекцію встановлювали комплексно, 3 урахуванням епізоотологічних даних, клінічних ознак хвороби, патолого-анатомічних змін і результатів лабораторної діагностики (лабораторія «Бальд», м. Київ).

Патолого-анатомічний розтин чотирнадцяти трупів котів проводили методом часткової евісцерації [2]. У ході проведення патологоанатомічного розтину для гістологічних досліджень відбирали шматочки з різних ділянок печінки. Відібрані шматочки фіксували в $10 \%$-му водному нейтральному розчині формаліну й після зневоднення в етанолах зростаючої концентрації через хлороформ заливали в парафін. Зрізи товщиною 7-10 мкм одержували за допомогою санного мікротому [3]. Для виявлення гістологічної будови органів і тканин проводили фарбування зрізів гематоксиліном Караці та еозином [1].

Результати досліджень. У ході проведення гістологічних досліджень печінки котів, які загинули від каліцивірусної інфекції, нами було встановлено, що всі центральні вени печінкових часточок виразно розширені, більшість із них переповнені клітинами крові. Гематокрит був помітно порушений: на плазму крові в площині гістологічного зрізу припадало лише від 5,1 до 8,4 \% просвіту кровоносної судини.

* Науковий керівник-доктор ветеринарних наук, професор Б. В. Борисевич 
Тканина печінки була дифузно набрякла. Внаслідок такого набряку втрачалася чітка мікроскопічна будова органа. В печінкових часточках лише місцями реєструвались окремі фрагменти печінкових балок, розміри яких не перевищували 10-12 розташованих поряд клітин. Проте навіть у багатьох таких залишках печінкових балок більшість гепатоцитів, які їх формували, були частково чи повністю дискомплексовані, що свідчило про значні порушення клітинних контактів.

Більшість гепатоцитів знаходилась у стані зернистої дистрофії. Їх цитоплазма була тьмяною, нерівномірно зафарбованою еозином, межі між суміжними клітинами були нечіткі або ж взагалі не виявлялися. В частини клітин реєструвалися початкові стадії гідропічної дистрофії, за якої у цитоплазмі з'являлися поодинокі прозорі чи напівпрозорі вакуолі невеликих розмірів. Такі зміни вказують на прогресування дистрофічного процесу в гепатоцитах, оскільки загальновідомо, що зерниста дистрофія може бути початковою стадією інших дистрофій, у тому числі й гідропічної.

Ядра в частини гепатоцитів набували неправильно округлої форми внаслідок викривлення ядерної оболонки як усередину, так і назовні ядра. Крім того, в частини гепатоцитів як змінені, так і не змінені ядра були розташовані ексцентрично - на одному з полюсів клітини, безпосередньо біля ядерної оболонки.

Частина гепатоцитів знаходилась у стані переднекрозу, поскільки в них виявлялися глибокі дистрофічні зміни й відносно невеликі за розмірами ділянки руйнування ядерної оболонки, або ж конденсація хроматину біля ядерної оболонки 3 просвітленням нуклеоплазми (гіперхроматоз ядерної оболонки), що, відповідно до сучасних уявлень, розцінюється як передвісник загибелі

\section{БІБЛІОГРАФІЯ}

1. Горальський Л. П., Хомич В. Т., Кононський О. I. Основи гістологічної техніки і морфофункціональні методи дослідження у нормі та при патології. - Житомир : Полісся, 2005. - 288 с.

2. Зон Г. А., Скрипка М. В., Івановська Л. Б. Патолого-анатомічний розтин тварин. - Донецьк : ПП Глазунов Р. О., 2009. - 189 с.

3. Лили Р. Патологическая техника и практическая гистохимия. - М. : Мир, 1969. - 640 с.

4. Справочник по лечению собак и кошек с описанием лекарственных средств / И. В. Сидоров, В. В. Калугин - М. : Издательский дом «Оникс клітини. У той же час між дистрофічно зміненими гепатоцитами виявлялися некротизовані печінкові клітини, як поодинокі, так і їх невеликі групки з 2-5 клітин.

Поодинокі печінкові клітини руйнувалися. Паренхіма печінки була інфільтрована клітинами запалення: між гепатоцитами виявлялися нейтрофіли, моноцити, поодинокі базофіли та лімфоцити. Слід зауважити, що клітинна інфільтрація органа була нерівномірною - на одних ділянках реєстрували досить значну кількість клітин запалення (співвідношення таких клітин до гепатоцитів становило від 1:11 до 1:21), на інших ділянках кількість клітин запалення була меншою (співвідношення таких клітин до гепатоцитів становило від 1:34 до 1:47), тоді як на окремих ділянках клітини запалення взагалі не виявлялися.

Під капсулою органа в більшості тварин виявлялися досить великі ділянки некрозу гепатоцитів. Такі ділянки не мали різких границь: некротизовані гепатоцити були безпосередньо оточені живими печінковими клітинами. Некроз гепатоцитів характеризувався каріолізисом. Інфільтрація клітинами запалення у вогнищах некрозу гепатоцитів та в безпосередньо прилеглих до них ділянках живої печінкової тканини нами не була зареєстрована.

\section{Висновки:}

1. У печінці котів, які загинули від каліцивірусної інфекції, нами виявлено виразні запальні зміни.

2. Запалення печінки супроводжувалося дистрофічними змінами та некрозом гепатоцитів.

Надалі доцільно провести гістологічні дослідження інших органів і тканин котів, які загинули від каліцивірусної інфекції, для встановлення в них характеру патоморфологічних змін.

XXI век», 2001. - $576 \mathrm{c.}$

5. Чандлер Э. А., Гаскелл К. Дж, Гаскел Р. М.; Пер. с англ. / Болезни кошек. - Аквариум-Принт, 2002. $-696 \mathrm{c}$.

6. Dawson S. (1991) Studies on feline calicivirus and its role in feline disease. $\mathrm{PhD}$ thesis, Universitiy of Liverpool.

7. Knowles J. O., McArdele F., Dawson S., Carter S., Gaskell C. J. \& Gaskell R. M. (1991) Stydies on the role of feline calicivirus in chronic stomatitis in cats. Vet. Microbiol. - 27, 205. 